\author{
Beata Stefaniak-Maślanka
}

beata.stefaniak@op.pl

\title{
Czary nad kołyską. Magia słowa w kołysance ludowej i lirycznym wierszu kołysankowym
}

\begin{abstract}
Stefaniak-Maślanka Beata, Czary nad kotyska. Magia stowa w kotysance ludowej i lirycznym wierszu kotysankowym (Spells at the Cradle. The Magic of Words in Folk and Lyrical Lullabies). „Poznańskie Studia Slawistyczne” 3. Poznań 2012. Adam Mickiewicz University Press, pp. 159-171. ISBN 978-83-232-2473-0. ISSN 2084-3011.

The article focuses on some examples of magic in traditional folk lullabies and lyrical lullabies for children. The aforementioned types of genre should invoke child's sleep by using special words or melody. On the other hand, traditional lullabies were used to protect children or bring them health and happiness. To accomplish this, the singer often called some „higher being” for help. In the article that kind of speech acts are considered as magical behavior. The second part of the text discusses use of language, character of content and some special procedures in lyrical lullabies, that can be called „magical”. This kind of magic is, however, created by lullaby authors, who practice it as an intentional method to „do things with words".
\end{abstract}

Keywords: lullaby, speech act, linguistic magical behavior, paidia

Antologię kołysanek w opracowaniu Jolanty Kowalczykówny otwiera cytat z wiersza Anny Kamieńskiej: „Róża nie zakwitnie / jak się nie polewa / dziecko nie urośnie, / jak się mu nie śpiewa"1. Kołysanka jako piosenka śpiewana $\mathrm{w}$ celu uśpienia dziecka ma $\mathrm{z}$ góry założone zadanie i towarzyszy jej intencja życzeniowa. W literaturze przedmiotu pojawiają się uwagi o wierze w magiczne właściwości kołysanek ${ }^{2}$, o bliskości kołysanki

${ }^{1}$ Luli, luli..., wyb. i wstęp J. Kowalczykówna, Lublin 1988, s. 3 [dalej LL].

${ }^{2}$ E. Mackinlay, Music for Dreaming: Aboriginal Lullabies in the Yanyuwa Community at Borroloola, Northern Territory, „British Journal of Ethnomusicology” vol. 8, 1999, s. 100. 
i hipnozy ${ }^{3}$, kołysanek i zaklęć ${ }^{4}$. Włoski badacz Glauco Sanga wyróżnia nawet specyficzną grupe kołysanek magicznych ${ }^{5}$ i zalicza do niej utwory, w których bezpośrednio przywołuje się personifikowany sen. Niniejszy artykuł omawia wybrane kołysanki i wiersze kołysankowe ${ }^{6}$ w kontekście pojawiających się w nich „magicznych” zabiegów i śladów myślenia magicznego.

\section{Magiczny entourage kołysanki}

Kołysanka, jak pisze Zofia Adamczykowa, ,wywodzi się z pieśni ludowych, a ściślej - z jednej z odmian, jaką są pieśni rodzinne. Jest zatem tworem obrzędowo-magicznym, w którym ujawnia się odwieczny archetyp matki-piastunki" ${ }^{\prime}$. Matka często jest w kołysankach postacią najważniejszą. Jej emocje, miłość i czułość wyrażane przy kołysaniu mogą decydować o magicznej mocy kołysanek: „odczuwanie miłości macierzyńskiej, spokoju, melodii słowa daje kołysance moc «uzdrawiania», której dziecko

${ }^{3}$ K. Bilica, Nad kotyskq. O kotysance, kotysankach Niekrasowa i „Kotysance Jeriomuszki” Musorgskiego, w: Muzyka i liryka, z. 2: Forma i ekspresja w liryce wokalnej 18081909. Interpretacje, red. M. Tomaszewski, Kraków 1989, s. 57-58, 72.

${ }^{4}$ V. Golovin, Russkaja kolybel'naja pesnja v fol'klore i literature, Turku 2000, s. 90103 oraz E. Mackinlay, op. cit., s. $100 \mathrm{i}$ in.

${ }^{5}$ L. Del Giudice, Ninna-nanna-nonsense? Fears, Dreams, and Falling in the Italian Lullaby, „Oral Tradition” 3/3, 1988, s. 271.

${ }^{6}$ W artykule wykorzystano następujące źródła: LL; Uśnij mój ty aniołeczku (kołysanki), oprac. J. Adamowski, Lublin 1991; Polska pieśń i muzyka ludowa. Źródta i materiaty, red. J. Bartmiński, t. 4: Lubelskie, cz. 3: Pieśni i teksty sytuacyjne, Lublin 2011; K. Turek, Ludowe kotysanki na Ślasku i w Zagtębiu Dąbrowskim: przegląd źródet i problematyki, s.1. 1985, s. 1; Rodzynki z migdałami. Antologia poezji ludowej Żydów polskich, przeł. J. Ficowski, Wrocław 1988 [dalej RzM]; Pieśni ludowe ze Ślaska, t. III, z. 2: Pieśni rodzinne, oprac. J. Ligęza, Katowice 1961 [dalej PŚl]; utwory zebrane w ramach akcji gromadzenia kołysanek w ,Wiśle”; liryki J. Czechowicza i D. Wawiłow oraz teksty cytowane w literaturze przedmiotu. Jako kontekst zostały wykorzystane kołysanki w języku czeskim i rosyjskim (źródło: V. Golovin, op. cit.; <http://lullabiesofeurope.wetpaint.com/> [dostęp: 26.07.2012]; <http://rosyjski.bukwa.pl/Kultura_rosyjska/Zabawa_po_rosyjsku/Kolysanki_po_rosyjsku.ht ml> [dostęp: 26.07.2012]). Źródła zostały dobrane tak, aby uzyskać próbę złożoną z tekstów z różnych regionów Polski i reprezentatywnych wierszy kołysankowych (oprócz utworów Czechowicza i Wawiłow przeanalizowano wiersze autorów ze zbioru LL).

${ }^{7}$ Z. Adamczykowa, Kotysanka - poezja wczesnego dzieciństwa, w: eadem, Literatura dla dzieci. Funkcje, kategorie, gatunki, Warszawa 2001, s. 111. 


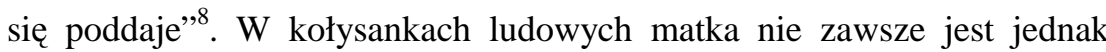
pełną miłości opiekunką, niekiedy narzeka na dziecko, złości się, spieszy. Na negatywny efekt kołysania mogły wpływać zarówno złe emocje matki, jak i - w kulturze ludowej - zaniechanie odpowiednich zabiegów towarzyszących usypianiu. Wśród ludów słowiańskich wiele reguł dotyczyło np. kołyski. Nie można było stawiać jej przy oknie, przenosić, podawać nad nią przedmiotów, zabierać z niej słomy, wyrzucać, kołysać pustej. Szczególne nastawienie do kołyski ujawniało się zwłaszcza przy ostatnim zakazie. Na obszarze Słowiańszczyzny powszechny był przesąd, że kołysanie pustej kolebki może sprowadzić chorobę, śmierć lub odebrać dziecku sen ${ }^{9}$. Henryk Biegeleisen tego typu zachowania odczytuje jako przypisywanie kołysce mistycznego znaczenia ${ }^{10}$. Tę interpretację zdają się potwierdzać występujące w kołysankach zwroty do kolebki:

Kołyszże się kołysz / kolebino z wieczkiem / Uśnij, nie płakusiaj / Z małym dzieciąteczkiem $^{11}$

Oj, kołysz mi się, kołysz / kolibeńko lipowa, / oj, niechże mi się w tobie / ta dziecina wychowa ${ }^{12}$.

Kołyska jest w nich antropomorfizowana i staje się jednym z adresatów, których matka prosi o pomoc w usypianiu. Gdy dziecko nie chciało spać, pomagały także inne sposoby, np. magiczne zabiegi wiążące się z zeskrobywaniem wapna ze ścian i wypowiadaniem zaklęć ${ }^{13}$.

Ślady magicznych zabiegów i przekonań związanych z kołysaniem zawierają „najstarsze rymy” towarzyszące człowiekowi od początku jego historii, wpisane w sferę magiczną i wierzeniowa, jak Jerzy Cieślikowski określił kołysanki. Pierwotnie były one tworami synkretycznymi, w któ-

${ }^{8}$ A. Ungeheuer-Gołąb, Poezja dzieciństwa, czyli Droga ku wrażliwości, Rzeszów 2004, s. 40.

${ }^{9}$ K. Bilica, op. cit., s. 64. Cf. J. Cieślikowski, Wielka zabawa. Folklor dziecięcy, wyobraźnia dziecka, wiersze dla dzieci, Wrocław 1985, s. 75-76.

${ }^{10} \mathrm{H}$. Biegeleisen, Matka i dziecko w obrzęach, wierzeniach i zwyczajach ludu polskiego, Lwów 1927, s. 164

${ }^{11}$ Ibidem, s. 165.

${ }^{12}$ Uśnij mój..., op. cit.

${ }^{13}$ Cf. F. Kotula, Znaki przeszłości. Odchodzace ślady zatrzymać w pamięci, Warszawa 1976, s. 183. 
rych najważniejszą rolę odgrywała bliskość matki (kołysanie w ramionach analogiczne do kołysania w łonie), miarowy ruch, rytm i spokojna melodia. Gestom z czasem zaczęły towarzyszyć słowa ${ }^{14}$.

\section{Magia aktów mowy}

Kołysanka użytkowa jako utwór o jasnej intencji prymarnej stanowi performatyw zbudowany z pojedynczych aktów mowy ${ }^{15}$. Elementarną formą kołysanki jest pojedyncza illokucja, której skutkiem ma być zrozumienie przez odbiorcę nakazu snu, a przewidywanym efektem perlokucyjnym - zaśnięcie. Aby to osiagnnąć, często wykorzystuje się w kołysankach prośby i polecenia: zaśnij, śpij, stul oczka itp. Obok bezpośrednich zwrotów do adresata (ich skuteczność nie będzie w tym artykule omawiana) w kołysankach obecne są także zwroty do natury czy instancji wyższej. Takie akty mowy dają się interpretować jako tzw. mowne zachowania magiczne. Sprowadzają się do prośby, której odbiorcą jest istnienie obdarzone mocą. Anna Chudzik pisze o podwójnej roli tego typu aktów:

Stworzenie gestaltów magicznych działań w stosunku do zjawisk nierozumianych, budzących lęk, pozwala je zrozumieć i oswoić, ciągle też podejmowane są „sprawdzone” schematy działań magicznych w stosunku do nowych zjawisk zagrażających poczuciu bezpieczeństwa ${ }^{16}$.

Mogą być wypowiadane z intencją zmiany rzeczywistości, ale także po to, aby zachować istniejący stan rzeczy, a więc w funkcji ochronnej:

${ }^{14}$ J. Cieślikowski, op. cit., s. 74. Najstarsze znane fragmenty kołysanek pochodzą ze starożytności. W twórczości europejskiej znajdujemy zapisy z XIII, XIV w. Kołysanki polskie zaczęto spisywać w XIX w. (J. Cieślikowski, op. cit., s. 75-77; K. Bilica, op. cit., s. 83). Na temat kołysanek vide: E. de Schoultz-Adajewska, Kotysanka ludowa, „Wisła. Miesięcznik Geograficzno-Etnograficzny” z. 4, 1894; R. Waksmund, Dzieci-plemię nieznane. Od folklorystyki do etnografii dzieciństwa; Dziecko $w$ świetle polskiej etnografii i folklorystyki, ,Literatura Ludowa” nr 4-5, 1996; Wokót dziecka. Kotysanki i pieśni dziecięce, Kolekcja muzyki ludowej Polskiego Radia, Warszawa 2009 [CD].

${ }^{15}$ Zwłaszcza z próśb, gróźb, nakazów, obietnic, zachęt do spania, przekupywania, straszenia, skarg, połajanek (wszystkie mają wspólną nadrzędną intencję uśpienia dziecka).

${ }^{16}$ A. Chudzik, Mowne zachowania magiczne w ujęciu pragmatyczno-kognitywnym, Kraków 2001, s. 45. 
Formuły magiczne o funkcji ochronnej służyć mają zabezpieczeniu obecnego stanu rzeczy - uważanego za pożądany, przed zmianami na inny - gorszy. (...) Formuły ochronne są specyficznym rodzajem wypowiedzi stwarzających, ale wyróżniają je określone skutki perlokucyjne, którymi w każdym wypadku jest nałożenie na aktualny stan rzeczywistości warstwy ochronnej, utrudniającej czy nawet uniemożliwiającej ingerencję weń zjawisk negatywnych ${ }^{17}$.

Mowne zachowania magiczne nie ograniczają się do kultury ludowej. Towarzyszą ludziom także współcześnie:

codzienność zdawałoby się powinna być całkowicie zracjonalizowana na miarę zracjonalizowanego przez naukę mechanistycznego kosmosu. W istocie jest ona pełna swoistych treści „mistycznych”, jest tęsknotą za sensem, jest z gruntu irracjonalna. Jest ona bezustanną modlitwą i obrzędem ${ }^{18}$.

Zarówno tradycyjne, jak i współczesne zachowania magiczne mogą przybierać formę ,modlitewnych, uspokajających czy proszących formuł wypowiadanych w stanach napięcia emocjonalnego"19. Funkcja magiczna realizuje się w nich tak w zakresie wywoływania zmian w rzeczywistości fizycznej, jak i psychicznej - wymawianie odpowiednich zwrotów działa kojąco, wzmaga poczucie bezpieczeństwa i zaspokaja potrzeby emocjonalne nadawcy. $W$ takim ujęciu mniej istotne jest to, czy nadawca wierzy w moc wypowiadanych słów, czy jedynie powtarza je ,na wszelki wypadek" lub z przyzwyczajenia. Nawet jeśli nie nastąpi dzięki nim zmiana rzeczywistości zewnętrznej, zadziałają w sferze emocji, a więc spowodują pewną zmianę rzeczywistości psychicznej. Jest to jeden z poziomów, na których magia kołysanki pomaga matce. Dzięki mownym zachowaniom magicznym zapewnia ona sobie i dziecku bezpieczeństwo i opiekę, ale już samo śpiewanie kołysanek, wyrażanie w nich lęku, bólu, złości, trudnych emocji, może przynieść jej ulgę i działać terapeutycznie ${ }^{20}$.

${ }^{17}$ Ibidem, s. 112-113.

${ }^{18}$ Ibidem, s. 81.

${ }^{19}$ Ibidem, s. 11.

${ }^{20}$ Przez długi czas (w niektórych kulturach do dziś) kołysanki stanowiły jedną z niewielu form pozwalających kobietom na swobodną wypowiedź i wyrażenie negatywnych emocji. Cf. J. Cieślikowski, op. cit., s. 74-75; H. Salimi, Les berceuses des mères kurdes, „La Revue de Teheran. Mensuel Culturel Iranien en langue française” nr 43, 2009; M.B. McDowell, Folk lullabies: songs of anger, love and fear, „Women's Studies” vol. 5, 1977. 


\section{Mowne zachowania magiczne w kołysance ludowej}

Kołysanki ludowe stanowią tę odmianę gatunku, w której melodia i rytm mają realną moc sprawczą i to przede wszystkim one usypiają. Zaspokojenie innych potrzeb wiązanych z kołysanką łączy się z wykorzystaniem mownych zachowań magicznych. Mowa tu zwłaszcza o szczególnym typie próśb i gróźb ${ }^{21}$, które da się zinterpretować jako słowne rytuały stwarzające i ochraniające w typologii Anny Engelking ${ }^{22}$.

Pierwszą grupę tworzą prośby o pomoc w uśpieniu dziecka i opiekę. Można się tu dopatrzyć śladów myślenia magicznego, zgodnie z którym cała natura, a także wszelkie przedmioty mogą wpływać na los człowieka. Mieszczą się tu wspomniane zwroty kierowane do kołyski oraz fragmenty wskazujące na postaci wraz z matką usypiające dziecko:

A-a, kotki dwa, / (...) / Nic nie będą robiły, / tylko dziecko bawiły. / Jak się kotki rozigrały, / to dziecinkę kolebały ${ }^{23}$,

A kołysały się / ptaski na badylu, / śpiewały Marysi: / lulu, Maryś, lulu²,

Lulajże mi, lulaj, / bodajżeś mi spało ${ }^{25}$.

Zwroty tego rodzaju nie muszą mieć typowej struktury prośby jak w trzecim przytoczonym przykładzie (bodajżeś = 'Bóg daj, żebyś'). Strukturalnie tego rodzaju wypowiedzi są często opisem sytuacji przeszłej, teraźniejszej albo przyszłej: „Uśnijże mi, uśnij / Pan Jezus cię uśpi”26, ale $\mathrm{w}$ istocie są to prośby, gdyż ich intencja jest życzeniowa. Wydaje się, że stanowią z jednej strony życzenie matki, aby dziecko zasnęło, z drugiej rzeczywistą prośbę do jakiegoś „istnienia”, które może zaopiekować się usypiającym i usypianym. Nadawca, wypowiadając zakamuflowaną prośbę, zakłada jej fortunność - przyjmuje, że instancja, do której się zwra-

${ }^{21}$ W funkcji mownych zachowań magicznych mogą być wykorzystywane (choć w tekstach zdarza się to rzadziej) także pozostałe akty budujące kołysanki.

${ }^{22}$ A. Engelking, Rytuały stowne w kulturze ludowej. Próby klasyfikacji, ,Język a kultura”, t. 4: Funkcje języka i wypowiedzi, red. J. Bartmiński, R. Grzegorczykowa, Wrocław 1991.

${ }^{23}$ LL, s. 15.

${ }^{24}$ Ibidem, s. 17

${ }^{25}$ Ibidem, s. 19.

${ }^{26}$ Ibidem, s. 29. 
ca, „ma wolę, aby zadośćuczynić życzeniu, prośbie, rozkazowi nadawcy, i uczyni to" ${ }^{27}$. W wielu polskich kołysankach ludowych adresatem słów matki są aniołowie, święci lub sam Bóg, przez co prośba zbliża się do modlitwy $^{28}$ :

Śpijże Staśku śpij, / A oczka zawrzej, / by stróż anioł z tobą spał, / Święty Józef, by cię kolebat ${ }^{29}$.

Uśpij mi sie, uśpij, synku, / jak usnąłeś wczora, / niech cie Pan Bóg tak usypia / każdego wieczora ${ }^{30}$.

O Pan Jezus uchowa / A duch święty cię unosi / Najświętsza Panienka / Oj niech za nami prosi. // O Najświętsza Panienko / Da ratuj że ty nas, ratuj / A nie daj nam ginąć / Da ginąć marnie ze światu ${ }^{31}$.

Odwołaniom religijnym mogą towarzyszyć formuły związane z ludowymi przekonaniami i zwyczajami; w poszczególnych utworach widoczne jest łączenie się reliktów myślenia magicznego i dominujących wierzeń: „Kołyszże się kołysko / kołyszże się lipowa / A niechże cię mój Staśku / Pan Bóg zdrowo uchowa"32.

Występowanie próśb do Boga czy świętych nie ogranicza się do kołysanek polskich. Podobne przykłady pojawiają się np. w kołysankach czeskich czy rosyjskich:

Spi, dětátko, spi, / zavři očka svý! / Pán Bůh bude s tebou spáti, / andělíčci kolébati ${ }^{33}$

Спи (...) со Христом. / Богородица с тобой, / Уж как ангелы хранители / В головучинах сидят ${ }^{34}$.

${ }^{27}$ A. Chudzik, op. cit., s. 56 .

${ }^{28} \mathrm{~W}$ literaturze przedmiotu pojawiają się uwagi o pokrewieństwie magii i religii: „Nie ma magii bez religii, nie ma religii bez magii. Każdy obrządek religijny: czy to modlitwa złożona z typowo schematycznych formuł, czy bezpośrednie zwrócenie się do Boga, czy też «tajemnica» komunii lub ślubu, modlitwa za czyjeś zdrowie lub nabożeństwo żałobne wszystko to są różnorodne objawy czynności rytualno-magicznych". L. Pełka, Pierwotne formy wierzén religijnych - magia i fetyszyzm, w: idem, Śladami pierwotnych wierzeń, Warszawa 1963, s. 62.

${ }^{29}$ Ibidem, s. 97.

${ }^{30} \mathrm{~K}$. Turek, op. cit., s. 70.

${ }^{31}$ Ibidem, s. 75.

${ }^{32}$ H. Biegeleisen, op. cit., s. 165 .

${ }^{33}<$ http://lullabiesofeurope.wetpaint.com/> [dostęp: 26.07.2012].

${ }^{34}$ V. Golovin, op. cit., s. 102. 
Баюшки-баю / Сохрани тебя / Ангел твой, / Сохранитель твой, / (..) / От всех скорбей, / От всех напастей ${ }^{35}$.

Opisane prośby pełniły funkcję ochronną, ale mogły również wiązać się z próbą zapewnienia dziecku szczęśliwego życia. W tym celu w kołysankach ludowych pojawiały się także tworzone przez matki projekcje przyszłości (zgodnie z wiarą, że to, co wypowiedziane, może się urzeczywistnić $^{36}$. Wyrazem tej samej intencji w kołysankach rosyjskich jest wprowadzanie do utworów motywu ptaków. Powszechnie uznawane za zwiastuny dobrego losu, obecne przy kołysce miały zapewniać dziecku pokój, zdrowie, a w przyszłości - płodność i bogactwo ${ }^{37}$.

Obok próśb w kołysankach ludowych często pojawiają się groźby o strukturze ,jeśli nie zaśniesz, to (stanie się coś złego)”. Mogą dotyczyć kary cielesnej, ale i tego, że ktoś przyjdzie, połknie lub porwie nieposłuszne dziecko. Tego typu groźby przechowują ślady myślenia magicznego kultura ludowa zna istoty (południce, topielice, mamuny, czarownice, zmory $\mathrm{i}$ in.) porywające lub podmieniające dzieci ${ }^{38}$. Co ciekawe, w polskich kołysankach nie ma postaci, które wzbudzały rzeczywiste obawy matek. „Złe” to raczej Cygan czy wilk:

Hulej, hulej, hulka / Zjod baranek wilka / A baranka wilcy / Niech Józefek mil$\mathrm{czy}^{39}$.

Lulajże mi, lulaj, / kołyseczko z wieczkiem, / idzie od Krakowa / Cyganeczka z dzieckiem ${ }^{40}$.

Mówienie o takich potworach pozwala na przekazywanie sensów inicjacyjnych (motyw wilka i baranka) czy wiedzy na temat stereotypów kulturowych (Cygan kradnie). To, że nie nazywano prawdziwych obiektów

${ }^{35}$ Ibidem.

${ }^{36}$ Motyw typowy np. dla kołysanek żydowskich (cf. RzM).

${ }^{37}$ S.A. Spitz, Social and Psychological Themes in East Slavic Folk Lullabies, „The Slavic and East European Journal" vol. 23, no. 1, 1979, s. 18.

${ }^{38}$ Cf. np. E. Diakowska, Z. Kłodnicki, Demony porywajace i odmieniajace dzieci, w: Komentarze do Polskiego Atlasu Etnograficznego, t. 9: Zwyczaje, obrzedy $i$ wierzenia urodzinowe, cz. 1: Zwyczaje, obrzędy $i$ wierzenia zwiazane $z$ narodzinami $i$ wychowaniem dziecka, Wrocław-Cieszyn 2010.

${ }^{39}$ PŚl, s. 96.

${ }^{40}$ LL, s. 30. 
lęku, przypuszczalnie wiązało się z tabu językowym, z wiarą, że słowo jest w stanie je przywołać.

Kołysankowe grożenie można interpretować jako złożone zachowanie magiczne, akt stwarzający o mocy warunkowej (wezwania: „by złe przyszło, jeśli dziecko będzie nieposłuszne” oraz ,aby nie przychodziło, jeśli będzie posłuszne"). Matka, grożąc, próbuje przekonać dziecko do zaśnięcia i daje mu do zrozumienia, że może zostać ukarane. Dyskusyjna jest kwestia wiary nadawcy w moc sprawczą takiej groźby. Dla odbiorcy jednak groźba matki jest zupełnie realna. Powodem jest nie tylko inny sposób pojmowania świata przez dziecko, ale również właściwy dla kultury ludowej pogląd, że:

Słowa matki wypowiadane do niedobrego dziecka spełniają się co do joty. Związek między matką a dzieckiem jest bowiem najsilniejszym z ludzkich związków (...) Jeśli [dziecko - B.S.M.] sprzeniewierzy się matce (...) matka, rzucając klątwę, symbolicznie zabiera życie, które dała ${ }^{41}$.

Przykładem utworu obrazującego zarówno istotę groźby jako środka perswazji, jak i moc matki, której słowa mogą się spełnić, ale która może też uchronić dziecko przed niebezpieczeństwem, jest przytoczona niżej kołysanka rosyjska pt.: Баю - баюшки - баю:

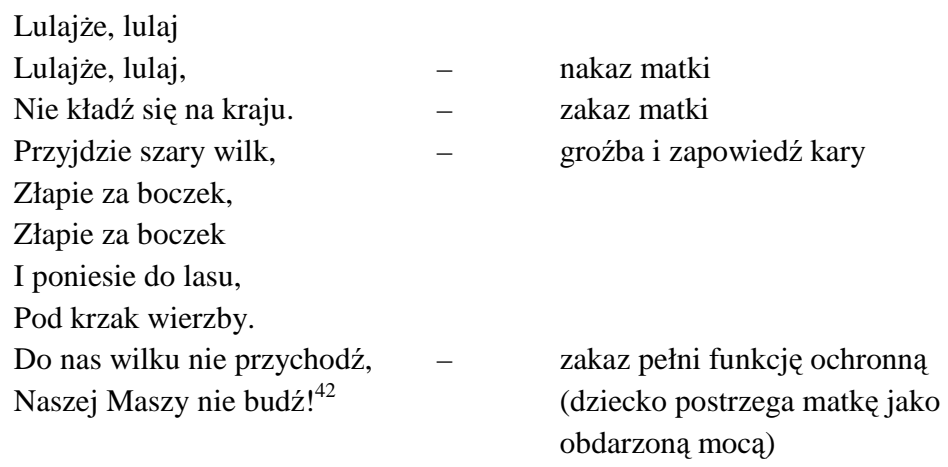

${ }^{41}$ A. Engelking, Magiczna moc słowa w polskiej kulturze ludowej, „Język a kultura”, t. 1: Podstawowe pojęcia i problemy, red. J. Anusiewicz, J. Bartmiński, Wrocław 1991, s. 160 .

42 <http://rosyjski.bukwa.pl/Kultura_rosyjska/Zabawa_po_rosyjsku/Kolysanki_po_rosyjsku.html> [dostęp: 26.07.2012]. 


\section{Magiczny wiersz kołysankowy}

Przy rozważaniu elementów magicznych w wierszach kołysankowych zwraca uwagę szczególna kreacja świata przedstawionego i uniezwyklenie w zakresie języka. Jak pisze Magdalena Jonca, rolę melodii przejmują w nich słowa. W poszczególnych utworach pojawiają się w związku z tym nowe treści i zmienia się prezentowany obraz świata - miejsce wiejskich realiów zajmują magiczne światy przeniknięte aurą baśni ${ }^{43}$. Usypia się nadal, choć rzadziej, korzystając z pomocy instancji wyższych (Boga, Anioła Stróża), zwykle jednak nadawca radzi sobie sam. Pozostaje przy bezpośrednich prośbach i groźbach kierowanych do dziecka i kreowaniu atmosfery sprzyjającej zaśnięciu. Tym razem kołysankowa opowieść ma oddziaływać magicznie, uspokajać i wyciszać, stąd fabuły często są oparte na przedstawianiu usypiającego świata. Takie opisy w polskich kołysankach na większą skalę pojawiają się dopiero w utworach liryczno-użytkowych. Obecne są także w kołysankach obcojęzycznych:

W lesie wilki śpią?

Śpią.

I motylki śpią?

Śpią.

W polu myszki śpią?

Śpią.

W kuchni łyżki śpią? ${ }^{44}$
Chmurka się uniża, wieczór się przybliża, śpij, śpij, syneczku, śpij...

Tupie deszcz po sadzie, nocka spać się kładzie, śpij, śpij, syneczku, śpij...

A jak uśnie nocka, synek zmruży oczka, śpij, śpij, syneczku, śpij... ${ }^{45}$
Спи, моя радость, усни. В доме погасли огни, Дверь ни одна не скрипит,

Мышка за печкою спит. Птички уснули в саду, Рыбки заснули в пруду.

Глазки скорее сомкни, Спи, моя радость, усни ${ }^{46}$.

Animizacje i personifikacje typowe dla wierszy kołysankowych przywodzą na myśl właściwe dla światopoglądu mitycznego przekonanie o wspólnocie człowieka i świata i ich wzajemnych sympatycznych związ-

${ }^{43}$ M. Jonca, Kotysanki i wiersze kotysankowe, „Literatura Ludowa” 1982, nr 2.

${ }^{44}$ D. Wawiłow, Senna piosenka, w: eadem, Dzieci w lesie, Warszawa 1991.

${ }^{45}$ J. Czechowicz, Kotysanki, w: LL, s. 36.

${ }^{46}$ <http://lullabiesofeurope.wetpaint.com/page/Lullabies+\%28Russian\%29> [dostęp: 26.07.2012]. 
kach. W utworach omawianej grupy pojawiają się m.in. ze względu na skłonność dzieci do zabawy i fantazjowania o tajemnym życiu przedmiotów. W czarodziejskim świecie wierszy kołysankowych żyją, mówią, kontaktują się z człowiekiem zwierzęta (np. koty i ptaki), rośliny (,stara wierzba stuka w okno (...) / nie strasz synka / stara wierzbo / lepiej bajkę

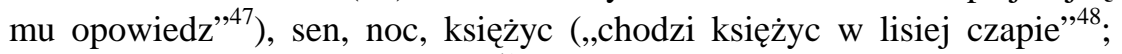
„noc opowiada zimowe baśnie" ${ }^{49}$; „Idzie sen do synka / poprzez senne morza" ${ }^{, 50}$ ), zabawki, ubrania.

Istotnym zabiegiem tworzącym magiczną aurę wierszy kołysankowych jest eksponowanie właściwości brzmieniowych języka. Na dużą skalę wykorzystuje się w nich instrumentację brzmieniową - znajdujemy tu sporo zbitek głosek szumiących, płynnych, miękkich. Dzięki odpowiedniemu doborowi słów, częstym powtórzeniom i uwydatnianiu walorów audialnych wiersze kołysankowe usypiają nie tylko treścią, ale i brzmieniem. Zbliżają się do szeptu, przez co usypianie świata przedstawione w treści znajduje odpowiednik w warstwie dźwięków.

Ze względu na dominującą pozycję dziecka w wierszach kołysankowych (w treści i formie przystosowanych do sposobu myślenia dziecka) wiele z nich można włączyć w zakres poezji paidialnej. Maria Ostasz, analizując dziecięce kołysanki, pokazuje dominujące w nich typy paidii (mimicry, agon, ilinx i alea). W opinii badaczki śpiewanie kołysanek wiąże się z rywalizacją pomiędzy matką i dzieckiem, w której matka chce sprawić, by dziecko zasnęło, natomiast intencją dziecka jest słuchanie możliwie najdłużej (agon). Matka, aby osiagnąć swój cel, stosuje powtórzenia i paralelizmy (ilinx). Na przykład opowiadając historię zasypiającego świata, próbuje sprowokować dziecko do naśladowania (mimicry), a więc podjęcia przedstawionego w tekście działania (zaśnięcia). Korzysta przy tym z ,magicznej mocy” neologizmów brzmieniowych, onomatopei, glosolalii oraz z „magiczności” w warstwie przedstawień (alea). Określone typy

${ }^{47}$ J.K. Weintraub, U kaczora srebrne pióra, w: LL, s. 89-90.

${ }^{48}$ Ibidem.

${ }^{49}$ T. Śliwiak, W zimowq noc (kotysanka), w: LL, s. 84.

${ }^{50}$ D. Wawiłow, Idzie sen do synka, cyt. za: K. Łysko, ,Strasznie ważna rzecz” - dziecięce postrzeganie świata $w$ wierszach Danuty Wawiłow, <http://j_uhma.republika.pl/wawilow2.html> [dostęp: 27.07.2012]. 
paidii wywołują konkretne zachowania dziecka ${ }^{51}$. Wykorzystanie tego pojęcia zwraca uwagę na celowość i intencjonalność stosowanych zabiegów konstrukcyjnych, treściowych czy stylistycznych.

Elementy o konotacjach magicznych obecne w wierszach kołysankowych są zasadniczo inne niż te, które można wyśledzić w ludowych kołysankach. W przypadku tych drugich można podejrzewać, że nadawca zachowań magicznych mógł wierzyć w ich moc - gdy wprowadzał do utworów modlitwy czy korzystał z formuł, robił to, aby osiagnąc realne korzyści (dobrobyt, zdrowie, opiekę). „Magia” służyła potrzebom nadawcy i oddziaływała na odbiorcę. W wierszach kołysankowych, które na pierwszy rzut oka wydają się w dużo większym stopniu przeniknięte magią, tego rodzaju zachowania magiczne pojawiają się rzadziej. W tej grupie utworów mamy do czynienia z kreowaniem świata, w którym dominuje myślenie magiczne, ale jest to świat tworzony na potrzeby adresata. To adresat, nie nadawca, może wierzyć w przedstawianą wizję, która ma prowokować sen. Świadomie wytwarzana przez nadawcę „magiczność” wiersza kołysankowego jest więc przede wszystkim środkiem służącym przekonaniu dziecka, by zasnęło.

„Odczarowywanie” kołysanki nasila się w utworach literackich, które nie pełnią funkcji użytkowej, ale treścią, stylem, budowa, przypominają dziecięce kołysanki. Mowa tu o kołysankach poetyckich, rozpowszechnionych w twórczości poważnej ${ }^{52}$. W tej grupie tylko niektóre utwory można rozpatrywać pod kątem performatywności. Większość nie jest przeznaczona dla dzieci i nie służy usypianiu. W wielu pojawiają się wyrażenia, które w kołysance użytkowej i użytkowo-literackiej stanowią akty illokucji (śpij, zaśnij, nie płacz, nie bój się itd.), a w niektórych także opisane mowne zachowania magiczne, jednakże w literaturze ich funkcja ulega zawieszeniu. O obecności i zmienionym statusie aktów mowy w literaturze pisze Richard Ohmann, analizując tekst B. Shawa:

${ }^{51}$ M. Ostasz, Od Konopnickiej do Kerna. Studium wiersza pajdialnego, Kraków 2008, s. 35-37, 39, 140-143 i in.

${ }^{52}$ Kołysanki poetyckie tworzą odmianę gatunku o dużej liczbie realizacji. Cf. D. Pawelec, Od kotysanki do trenów. Z hermeneutyki form poetyckich, Katowice 2006, s. 35; V. Golovin, op. cit. i in. 
w obrębie rzeczywistości dramatycznych (...) niektóre illokucje są fortunne, inne zaś nie (...), kiedy odnosimy te akty do ich rzeczywistych uczestników - autora, aktorów, słuchaczy - żaden z tych aktów nie jest ani nie może być fortunny. (...) Dzieła literackie są to wypowiedzi, w których zwykłe reguły illokucyjne zostały zawieszone, są to akty pozbawione swoich normalnych następstw ${ }^{53}$.

Problem magiczności w kołysankach poetyckich, ze względu na ich nieperformatywność i odmienny charakter, wymagałby odrębnych rozważań, dlatego też nie został w tym miejscu rozwinięty.

${ }^{53}$ R. Ohmann, Literatura jako akt, w: Teoretycznoliterackie tematy i problemy, wyb. D. Ulicka, Warszawa 2003, s. 425. 
